\title{
SMARTPHONE E-LEARNING PENETRATION ON COMPUTER SCIENCE AND COMPUTER EDUCATION STUDENTS
}

\author{
Ramadiani $^{1}$, Ahmad Nizar Hidayanto $^{2}$, Azainil $^{3}$ \\ ${ }^{1}$ Faculty of Computer Science and Information Technology Mulawarman University ${ }^{2}$ Faculty of Computer \\ Science, University of Indonesia \\ ${ }^{3}$ Faculty of Teacher Training and Education Mulawarman University, Indonesia \\ mmi ugm04@yahoo.com, nizar@cs.ui.ac.id, nil unmul@yahoo.com
}

\begin{abstract}
Level of smartphone usage can be used as an indicator of technological progress of a region. This study aims to explore the background of the selection of smartphones and applications used, as well as the level of internet consumption in students of Computer Science Department, Faculty of Computer Science and Information Technology, and Education of Computer Science students at Faculty of Teacher Training and Education in Mulawarman University as respondents. Total of respondent are 78 student which are consist of 33 females and 45 males. The research method used survey and descriptive analysis about User smartphone behavior and penetration. The purpose of the research is to development and to selection of Internet content according to the needs of students in computer science and in computer science education and to recommend supporting the lecture content, research and elearning.
\end{abstract}

Keywords: Smartphone Penetration, E-Learning, Mobile Learning, Smartphone app. 


\section{INTRODUCTION}

In today's digital age, the distance can be closer, the information path is wide open and easily spread so there is no more privacy in a country or household. Everyone can share information using cameras, pictures, sounds, text, and videos without bothering, and all goes very fast. Events in an area can be known to people from other areas in a matter of seconds. So do not be surprised if the smartphone into something that must be owned by everyone.

Smartphone user behavior also evolved into its own culture. Sharing selfie or group photos, snapping food before eating, opening and sending messages while walking or driving, creating status and sharing news in social media. Smartphone user behavior also affects a person's economic behavior, buyers will check and compare prices of goods from one place and another, order goods, buy tickets and pay online, online banking, traveling and health counseling (Ramadiani et.al., 2016).

According to Pew Research Center (2015) as many as 54 percent of adults in 21 developing countries are already using the internet. This figure is up from 43 percent in 2013. In addition to internet use, in developing countries also seen an increase in the use of smartphones. In 2013, there are 21 percent of adults who use smartphones. This figure rose to 37 percent in 2014. While in developed countries, as many as 87 percent of adults are internet users and 68 percent already have smartphones. In Indonesia, the rate of new smartphone users reached 21 percent with the internet user rate reached 30 percent (Smith, 2015).

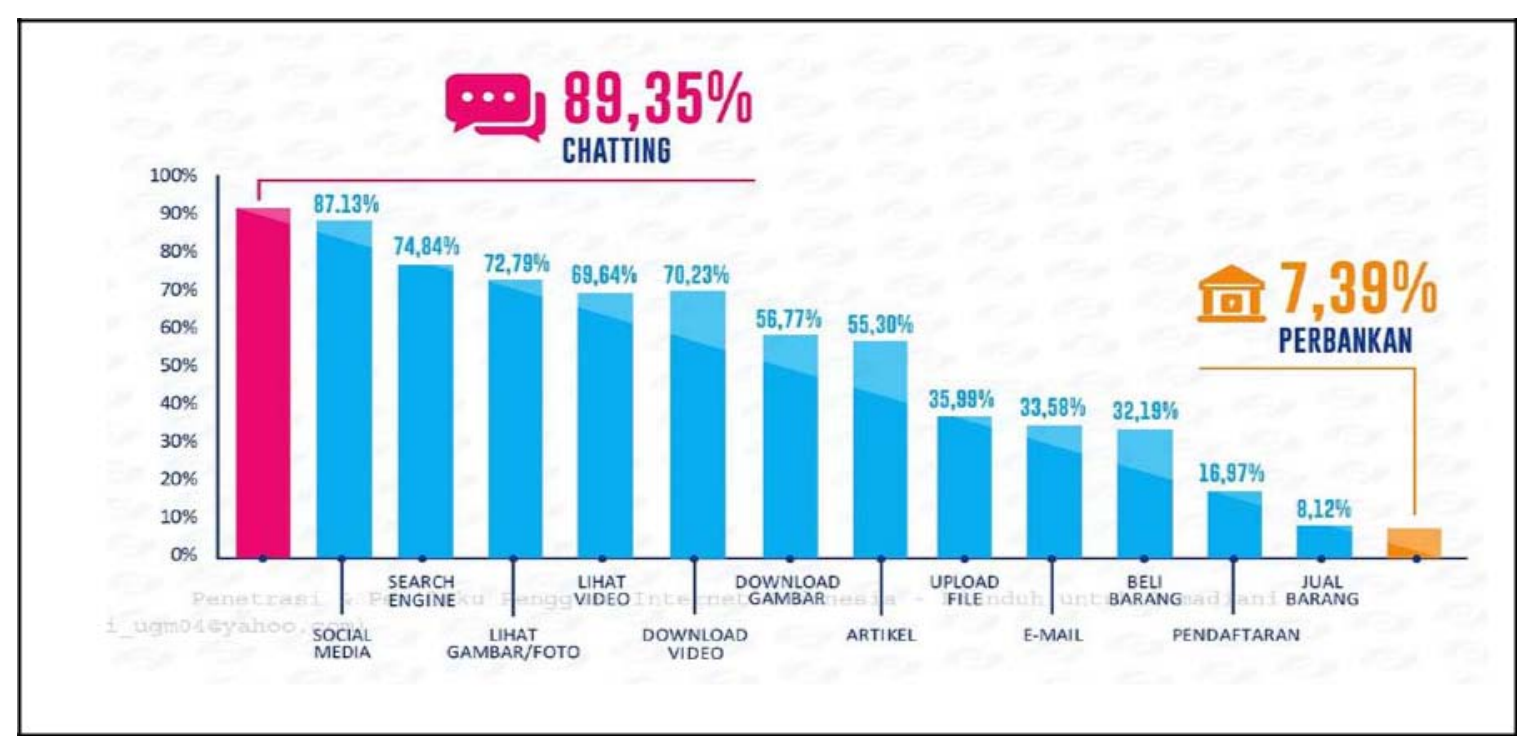

Figure 1. Internet users based on services accessed (APJII 2017) 
Smartphones are used for much more than calling, texting, or basic internet browsing. Users are turning to these mobile devices as they navigate a wide range of life events: $62 \%$ of smartphone owners have used their phone in the past year to look up information about a health condition. $57 \%$ have used their phone to do online banking. 44\% have used their phone to look up real estate listings or other information about a place to live. $43 \%$ to look up information about a job. $40 \%$ to look up government services or information. $30 \%$ to take a class or get educational content. $18 \%$ to submit a job application (Smith, 2015).

.Research TNS Australia states about 50 percent of smartphone owners in Indonesia to make the device as the main telecommunications equipment, including to access the internet. The penetration rate is the highest in Asia. However, from eight countries that became research sites in June 2015, penetration of smartphones in Indonesia by percentage is in the second lowest position. Only India whose mobile device penetration is lower than Indonesia (Bargshady et al., 2015).

Many people use mobile phones as the primary means of communication. The people who have a relatively high education or have a relatively high income have a higher tendency to use the internet or own a smartphone. Most internet or smartphone users use it to access social media. In countries where the price of internet access is relatively low, the number of social media users is more. For example, the Middle East and Latin America have social media users of 86 percent and 82 percent. While social media users in the US and Europe only reached 71 percent and 65 percent (Smith, 2015).

This is a list of countries by smartphone penetration in 2017. These numbers come from the annual Global Mobile Market Report and are based on a model which takes into account a country's economic progression, demography, online population, and inequality. These estimates are benchmarked with the clients in the industry along with third party reports and institutions. The Report features an extensive smartphone user forecast from 2015 to 2020 per country and region, along with the top smartphone and tablet brands, and app revenue forecasts (Global Mobile Market Report, 2017). 


\begin{tabular}{|c|c|c|c|c|c|}
\hline & & & & & APRIL $2017 \mathrm{~V}$ \\
\hline RANK & IMAGE & COUNTRY & $\begin{array}{l}\text { TOTAL } \\
\text { POPULATION }\end{array}$ & $\begin{array}{l}\text { SMARTPHONE } \\
\text { PENETRATION }\end{array}$ & $\begin{array}{l}\text { SMARTPHONE } \\
\text { USERS }\end{array}$ \\
\hline 1 & & China & $1,388,233,000$ & $51.7 \%$ & $717,310,000$ \\
\hline 2 & & India & $1,342,513,000$ & $22.4 \%$ & $300,124,000$ \\
\hline 3 & & United States & $326,474,000$ & $69.3 \%$ & $226,289,000$ \\
\hline 4 & & Brazil & $211,243,000$ & $37.7 \%$ & $79,578,000$ \\
\hline 5 & & $\begin{array}{l}\text { Russian } \\
\text { Federation }\end{array}$ & $143,375,000$ & $54.7 \%$ & $78,364,000$ \\
\hline 6 & & Japan & $126,045,000$ & $50.1 \%$ & $63,089,000$ \\
\hline 7 & & Germany & $80,636,000$ & $68.8 \%$ & $55,492,000$ \\
\hline 8 & & Indonesia & $263,510,000$ & $20.7 \%$ & $54,494,000$ \\
\hline 9 & & Mexico & $130,223,000$ & $40.7 \%$ & $52,993,000$ \\
\hline 10 & & United Kingdom & $65,511,000$ & $68.6 \%$ & $44,953,000$ \\
\hline 11 & & France & $64,939,000$ & $65.3 \%$ & $42,399,000$ \\
\hline 12 & & Turkey & $80,418,000$ & $49.8 \%$ & $40,010,000$ \\
\hline
\end{tabular}

Figure 2. The top 50 countries in terms of smartphone users in 2017

The biggest challenge in this study is how to evaluate the use of smartphones at Computer Science Department students FKTI UNMUL with Computer Science Education students FKIP Mulawarman University who can produce and recommend new innovations for applications and content that suits the needs of students of a region. Based on existing research, in the Asian market are only three applications that sell, namely instant messaging, WhatsApp or line, social media, and search engines. 


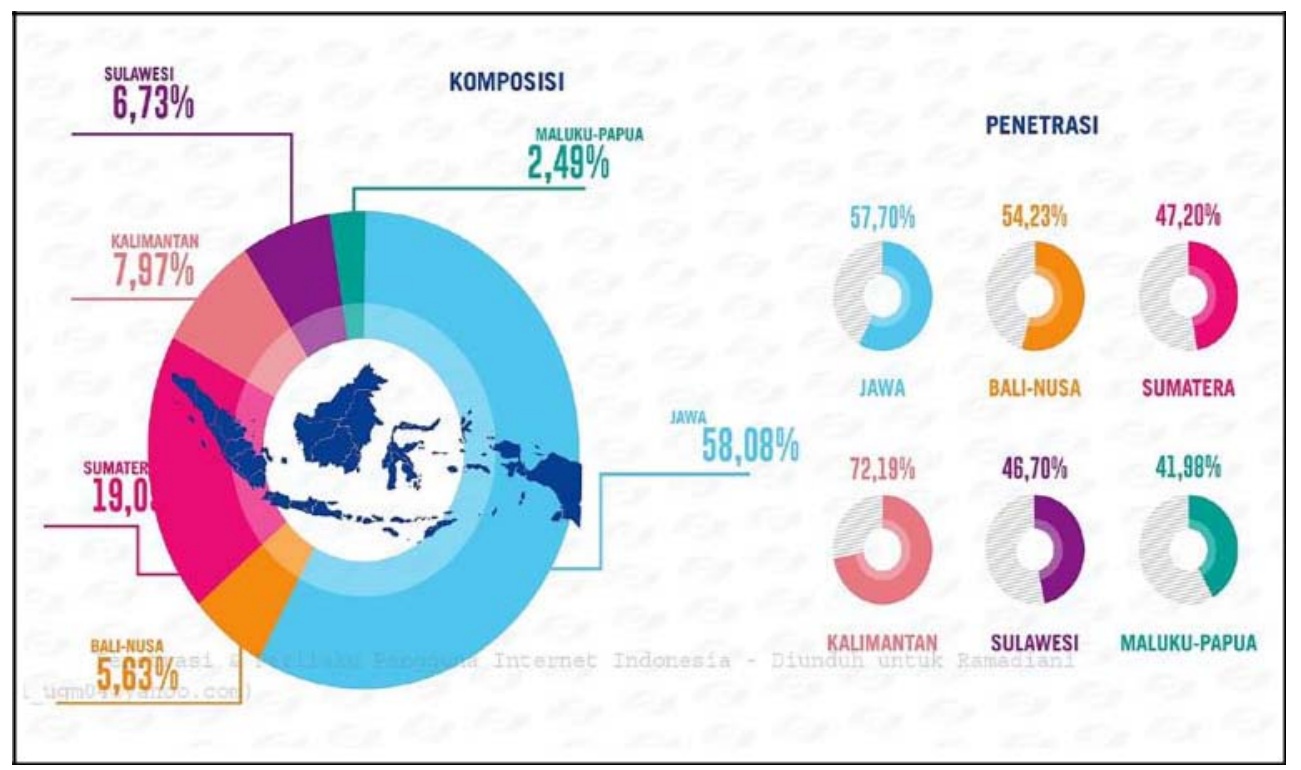

Figure 3. Internet User Penetration in Indonesia 2018

The Association of Internet Service Providers Indonesia (APJII) revealed the number of internet users in Indonesia reached 88 million people by the end of 2014. Based on population, the largest number of Internet users is in West Java province as many as 16.4 million, followed by East Java 12.1 million users and Central Java 10.7 million users. Fig. 3 is the Number of Internet Users by region in Indonesia (Rakhmani and Pangerapan, 2015).

\section{METHOD}

\section{A. Research Focus}

Internet users and smartphones worldwide are on the rise. The number of internet and smartphone users in developing countries is slowly but surely close to 100 percent [6]. Based on the background and focus of the research above, then the problems of this research are formulated as follows;

1) How to mapping the students consumption pattern according to smartphone usage?

2) What kind of content do they access to support their academic and learning activities? 
The components that will be evaluated in this research are focused on the following matters: User Smartphone Profile (user style, spent time, education background, age, sex, income) (Ramadiani et.al., 2013, 2016, 2017). The Smartphone usability such as knowability, operability, efficiency, robustness, safety, subjective satisfaction and smartphone user benefit is media element, communicativeness, user expectation (Ramadiani et.al., 2017).

\section{B. Structural Equation Model}

Structural Equation model (SEM) is an abbreviation of the structural equation model which is the second generation of multivariate analysis technique that allows researchers to examine the relationship between complex variables both recursive and nonrecursive to obtain a comprehensive picture of a model. Unlike regular multivariate analysis (multiple regression and factor analysis). SEM can perform testing together, namely: structural model that measures the relationship between independent and dependent construct, and measurement model that measures the relation (loading value) between the indicator variable and the construct (latent variable) (Ramadiani, 2010). With the incorporation of structural model testing and the measurement allows researchers to;

1) Testing measurement errors as an integral part of the structural equation model.

2) Conducting factor analysis simultaneously with hypothesis testing.

$$
\begin{aligned}
& \eta_{(\mathrm{m} \times 1)}=\mathrm{B}_{(\mathrm{m} \times \mathrm{m})} * \eta_{(\mathrm{m} \times 1)}+\Gamma_{(\mathrm{m} \times \mathrm{n})} * \xi_{(\mathrm{n} \times 1)}+\zeta_{(\mathrm{m} \times 1)} \\
& \mathrm{y}_{(\mathrm{p} \times 1)}=\Lambda_{\mathrm{y}(\mathrm{p} \times \mathrm{m})} * \eta_{(\mathrm{m} \times 1)}+\varepsilon_{(\mathrm{p} \times 1)} \\
& \mathrm{x}_{(\mathrm{q} \times 1)}=\Lambda_{\mathrm{x}(\mathrm{q} \times \mathrm{n})} * \xi_{(\mathrm{n} \times 1)}+\delta_{(\mathrm{q} \times 1)}
\end{aligned}
$$

Figure 4. General Structural Equation Model

\section{User Smartphone Behaviour}

The research aimed to identification students penetration of smartphone. This is the first step of three phases experiment was conducted in this research to get more information about user requirements to select smartphone. In this case, the researcher should build some questioner for evaluation user acceptance [(Ramadiani et.al., 2013, 2016, 2017). Based on the previous evaluations and theories about the user technology 
acceptance, we developed hypotheses and some questioners to collect, to prove and to support our research objectives.

\section{Data Collection Technique}

Respondents used Smartphone for over three months. We shared the questioners to identify their acceptance using the Smartphone. The questioners contain three types question; open answer, Lickert scales and demographic. Besides that, the questioner also consisted of user behavior; smartphone usability and smartphone benefit questions (Ramadiani et.al., 2013, 2016, 2017).

\section{1) Research Respondents}

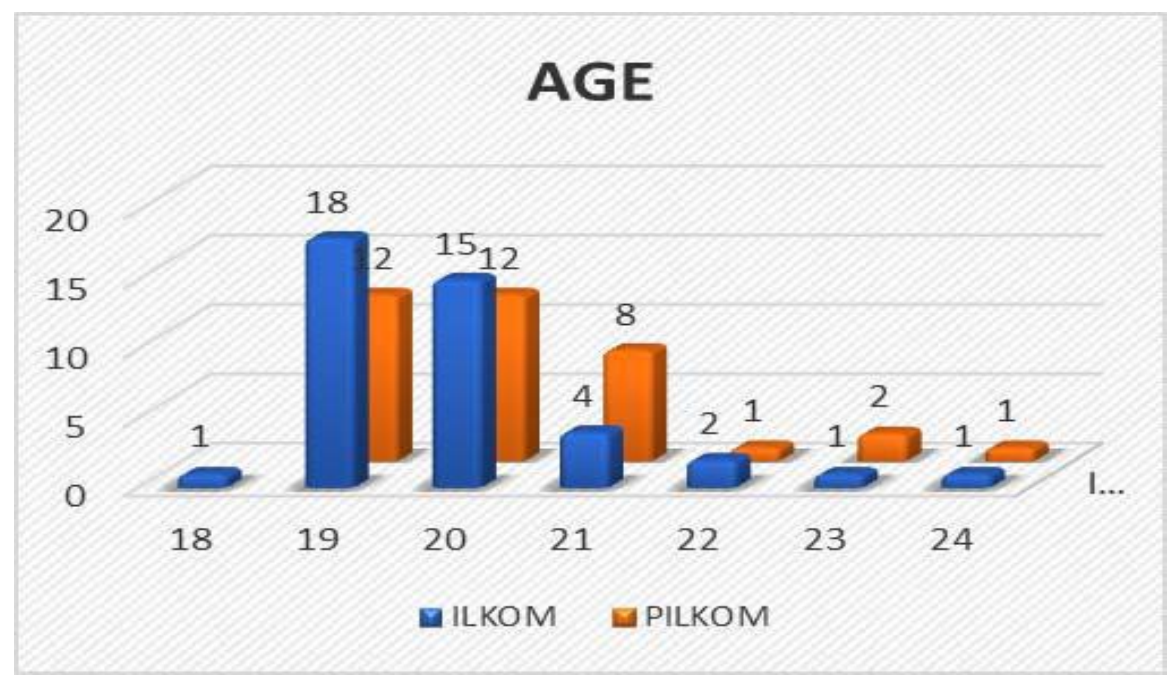

Figure 5. Research Participants

This research involved seventy-eight students as respondents (forty-five males and thirty-three females) from the students of Computer Science Department and students from Communication and Information Technology Department of Teacher Training and Education Faculty in Mulawarman University (Fig. 5).

\section{2) Evaluation Setup}

All the evaluation process was conducted during the class meeting in the in Mulawarman University, East Kalimantan. The observation was done in two months before the data research was collected by using questioners to identify the student behavior in searching materi by using smartphone and laptop penetration. 


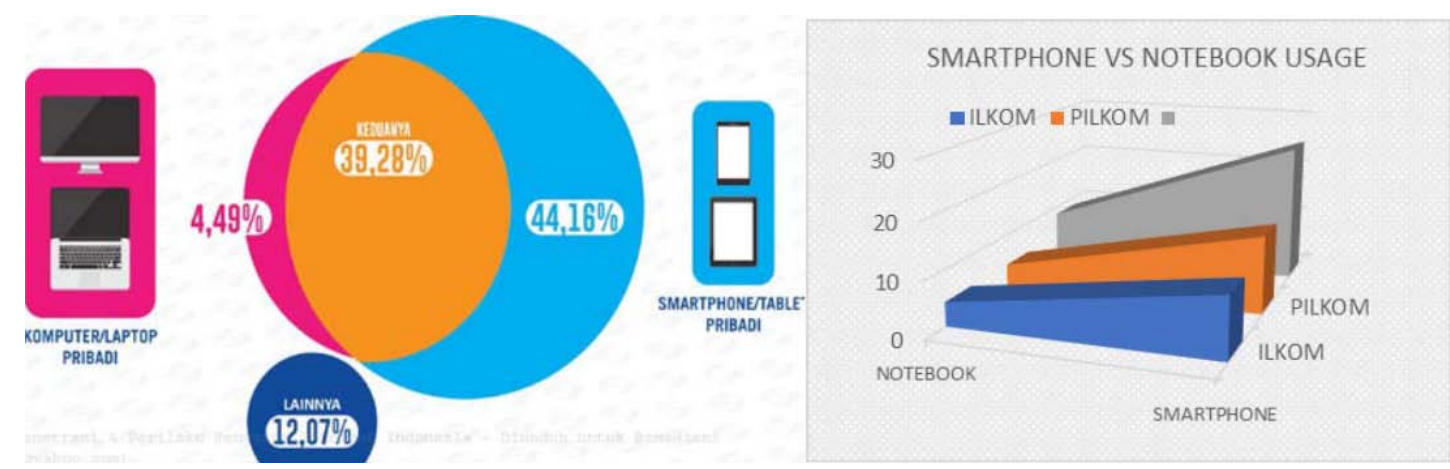

Figure 6. the use of smartphones is higher than notebooks according two studies

The use of smartphones is higher than the use of notebooks in accessing the internet. It is eight point five for notebook and fourteen point one for smartphone (Fig. 6). In Ilkom students are four point thirty three for the notebook and eleven for smartphone. In the other hand, Pilkom students are four point nineteen for the notebook and fourteen point one for smartphone.

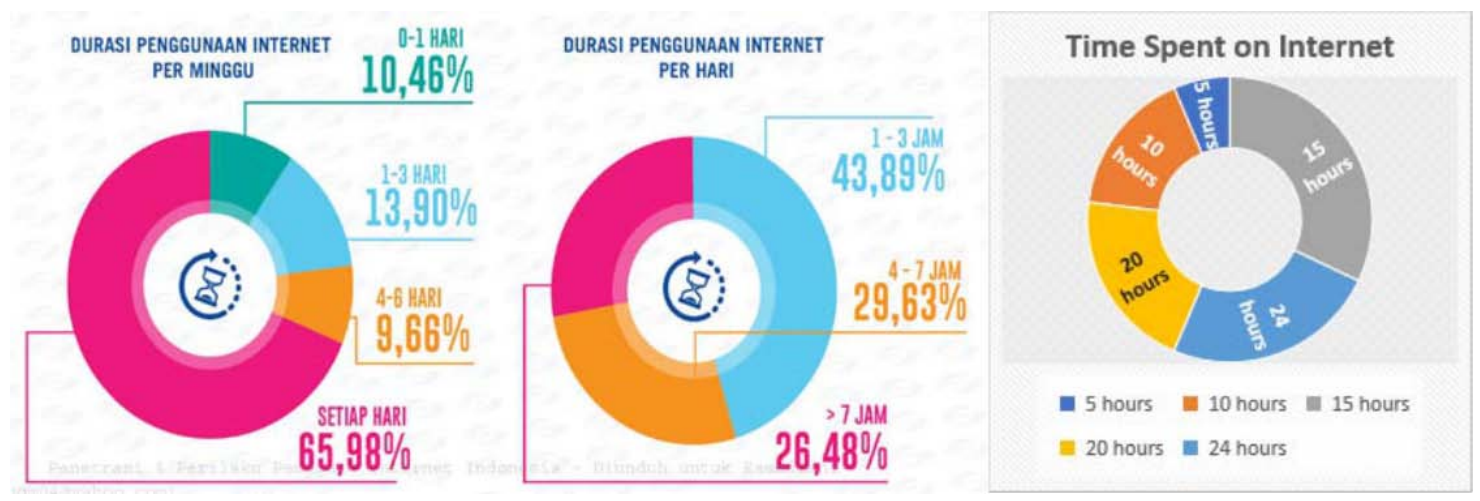

Figure 7. The students spent time for internet accsess according two studies

Fig. 7 almost all students spend a lot of time accessing the internet. They get an average of about 15.6 a day to spent on Internet usage. Five students use internet less than five hours, thirteen students use it less than ten hours, twenty-five students use fifteen hours, sixteen students use less than twenty hours and the last, nineteen students almost use internet for twenty hours a day. 

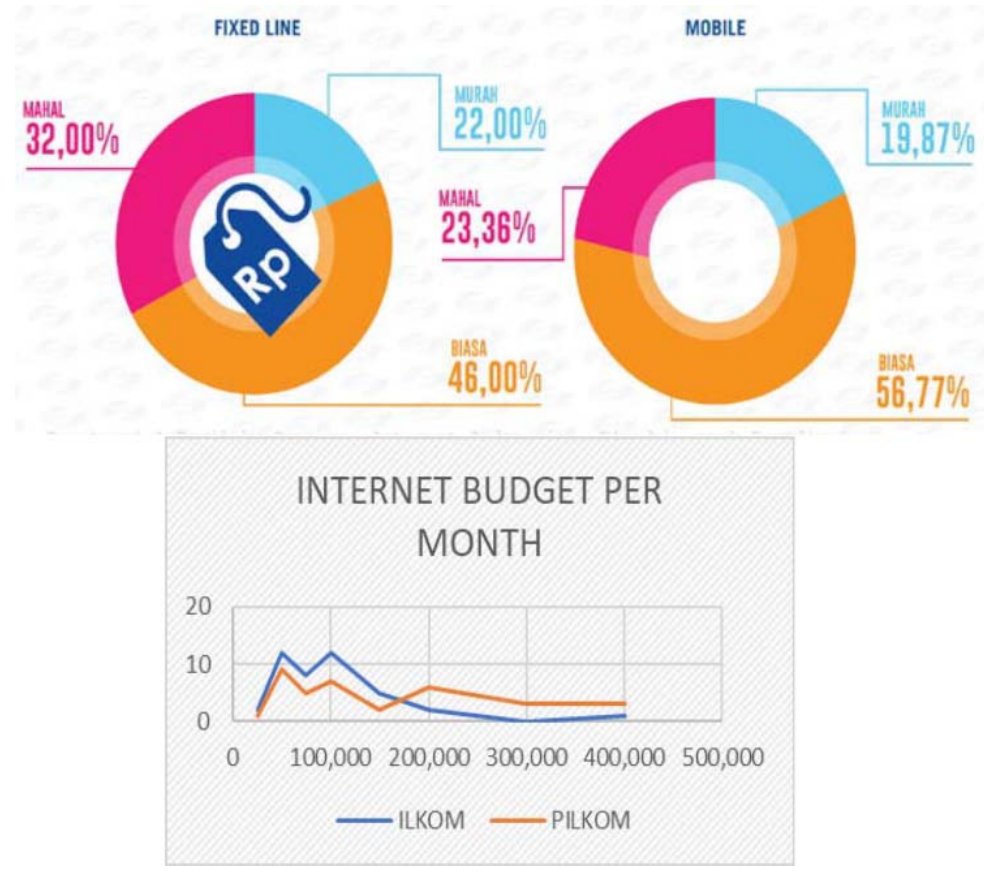

Figure 7. Internet budget per month according two studies

Students spent variative budget for internet cost per month (Fig. 8).

- Three students spent Rp.25.000,-/month,

- Twenty-one students spent Rp.50.000,-/month,

- Thirteen students spent Rp.75.000,-/month,

- Nineteen students spent Rp.100.000,-/month,

- Seven students spent Rp.150.000,-/month,

- Eight students spent Rp.200.000,-/month,

- Three students spent Rp.300.000,-/month, and

- Four students spent more than Rp.400.000,-/month. 


\section{RESULT AND DISCUSSION}

\section{A. User Smartphone E-Learning Penetration}

This is the research result 23 about student internet penetration using smartphone. The smartphones that students used in this research are variative to help them from any mindkind. The research was taken in February until April 2018. Most of them are teenagers are dominant using social media such as Line, Instagram, Whatsapp, and so forth as a means of communication and updates Information. Fig. 9 is the variative social media for the students network and communication.

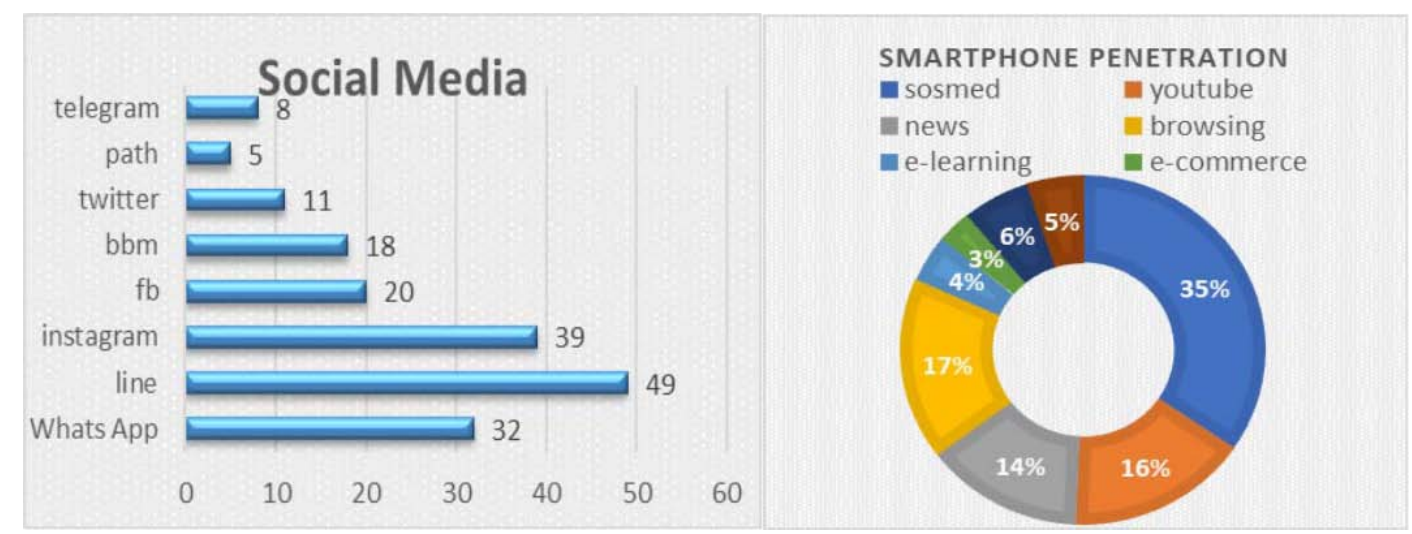

Figure 8. The Ranks of Social Media that the students used

The method used here is taking samples by spreading questionnaires to students of Computer Science Faculty of Computer Science and Information Technology and Computer Science Education Student Faculty of Teacher Training and Education Mulawarman University. Produced sample data from 78 respondents with ages between 18 to 24 years whose average age range of 20 years. Fig. 8 shows the students use smartphones to surf the Internet. Browsing news, playing games, using social media for communication, youtube, entertainment, news, email, E-commerce, E-learning applications, and so forth.

The users of these providers not only entrust internet access to one provider, the reasons vary such as; Three is chosen because it is cheap but the network is not found in some places and this will hinder the activity of surfing on the internet when they travel out, so they chose the ISP with Telkomsel is the strongest and the most users college student. Therefore we classify the data back into several parts with pegged to the provider who has the most service users are Telkomsel as many as 49 users. 


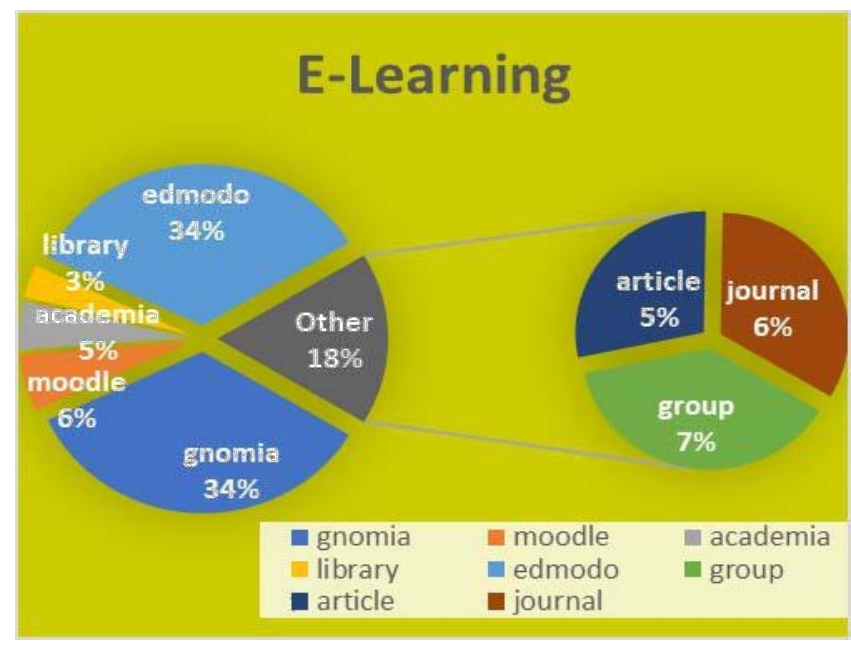

Figure 9 E-Learning Using Student Smartphone

Fig. 8 shows that the Social media is the first rank were used by $35 \%$ students per day, the second level is browsing $17 \%$, the third level is youtube were visited by $16 \%$ students, news are the fourth level in $14 \%$, then the fifth level is game $6 \%$, the email $5 \%$, e-learning $4 \%$ and e-commerce $3 \%$. Ini Fig. 9 we can see that still a few smartphone users access e-learning application. E-Learning applications used with smartphones are also limited compared to notebooks. Gnomia and Edmodo 34\%, Group 7\%, Moodle and journal 6\%, Academia and article $5 \%$, Library 4\%. Moodle is a well-known open-source Course Management System, with a large user community. The functionality is thus continuously being enhanced and the code is well maintained. Gnomio is a few moodle fans enjoying an unexpected success while offering free tools for the e-learning community. Edmodo takes learning beyond the classroom by providing a free, safe place for teachers and students to connect and collaborate, anytime, anywhere. Unlike an LMS, Edmodo lets us integrate and manage e-learning. 
TABle 1. Average USE OF SMARTPHONE AND NOTEBOOK

\begin{tabular}{|c|c|c|}
\hline $\begin{array}{c}\text { Type of } \\
\text { Activities }\end{array}$ & $\begin{array}{c}\text { The average use of } \\
\text { Smartphone }\end{array}$ & $\begin{array}{c}\text { The average of } \\
\text { notebook }\end{array}$ \\
\hline Social media & 4.882290641 & 1.834880769 \\
browsing & 2.303769231 & 2.181461538 \\
entertainment & 2.505355844 & 1.974124359 \\
gaming & 0.910615385 & 0.905432051 \\
e-learning & 0.084415584 & 0.179487179 \\
\hline TOTAL & 10.68644668 & 7.075385897 \\
\hline
\end{tabular}

From Table 1 it can be seen that smartphone usage is longer time than notebook usage. This is because the smartphone is a small-sized technology that functions almost equivalent to the notebook and easy to carry anywhere. On smartphone usage, the most popular activity is accessing social media. This is because the smartphone is a most advanced communication tool that can make conversations very easily. While the use of notebooks, the most widely performed is browsing. Browsing using a laptop is more effective than using a smartphone, because all websites can be accessed through the notebook perfectly. However, e-learning activities are the shortest activities of all activities, either through smartphones or notebooks (Fig. 10).
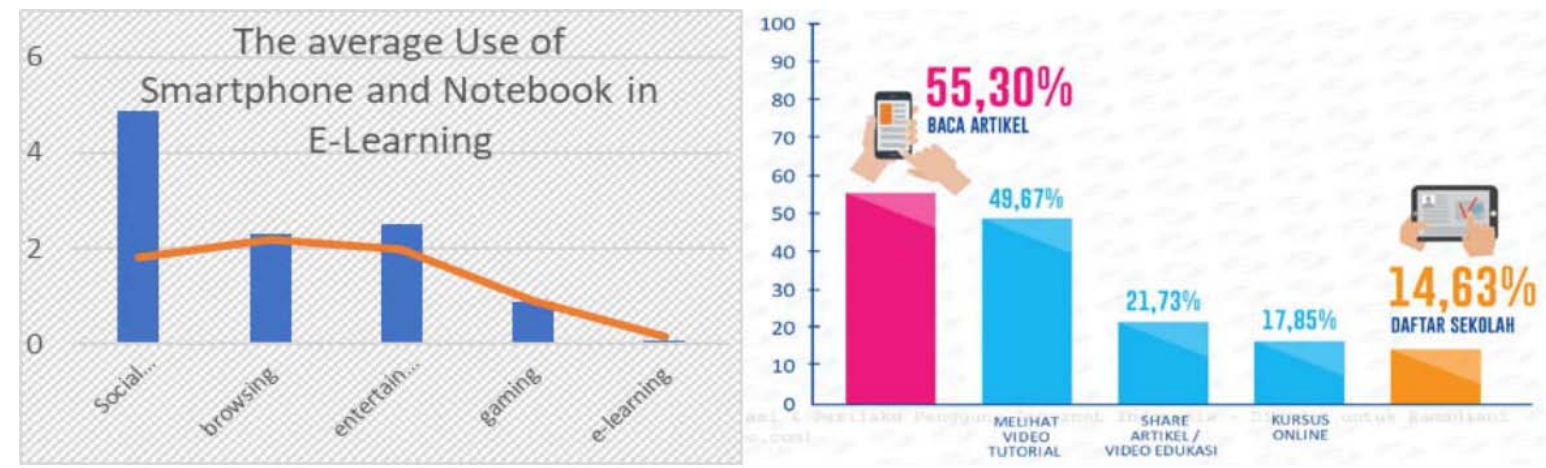

Figure 10. The Avarage use of E-Learning in Smartphone and Notebook 


\section{CONCLUSION AND SUGGESTION}

Smartphone is a communication tool whose ability is getting closer to the use of notebook. Although now the most popular activities performed on smartphones is accessing social media, but one day the smartphone can replace the function of the notebook in processing files and other important data. The most frequent activities of smartphone users are social media, group discussion, YouTube, browsing, games, download, e-commerce, and entertainment news. However, e-learning and other learning applications are the shortest activities of all activities, whether through smartphones or notebooks. This research is the preliminary research of three stages of research. Future research will test usability and user benefit to develop smartphone content that can be used for e-learning templates and other college tasks.

\section{REFERENCES}

Ramadiani, R. Atan, A. Rusli, M.H. Selamat, and Noeraini (2016). "Integrated Model Acceptance for E-Learning", International Conference on Engineering and Technology for Sustainable Development (ICET4SD) 11-12 Nov 2015, Yogyakarta, Indonesia IOP Conf. Series: Materials Science and Engineering vol.105, no.1 https://doi.org/10.1088/1757-899X/105/1/012016

Aaron Smith (2015) U.S. Smartphone Use in 2015. Pew Research Center.

Ghazal Bargshady et al. (2015) The Effective Factors on User Acceptance in Mobile Business Intelligence. Jurnal Teknologi (Sciences \& Engineering) 72(4): 49-54.

Asosiasi Penyelenggara Jasa Internet Indonesia (2017). PENETRASI \& PERILAKU PENGGUNA INTERNET INDONESIA 2017, HASIL SURVEY APJII 2017, pp:1-39.

Inaya Rakhmani and Semuel A. Pangerapan (2015) Profil Pengguna Internet di Indonesia 2014. APJII and PusKaKom UI.

Global Mobile Market Report, Markets. (2017). Top countries by smartphone users and penetration Trends \& Projections, https://newzoo.com/insights/rankings/top-50countries-by-smartphone-penetration-and-users/

Shannon Greenwood, Andrew Perrin and Maeve Duggan (2016). "Social Media Update 2016". Pew Research Center, November 11.

Lina Wu, Mincheol Kang and Sung-Byung Yang, (2015). What Makes Users Buy Paid Smartphone Applications? Examining App, Personal, and Social Influences. Journal Internet and Banking (JIBC) August 2015, Vol. 20, No.1 
Jin Baek Kim and Sungmin Kan. 2012. A Study on the Factors Affecting the Intention to Use Smartphone Banking: The Differences between the Transactions of Account Check and Account Transfer. International Journal of Multimedia and Ubiquitous Engineering Vol. 7, No. 3, July, 2012

D. Guralnick (2006) "How to Design Effective, Motivating User Interfaces", American Society for Training \& Development TechKnowledge Conference, Denver.

Ramadiani (2010) Structural Equation Model Untuk Analisis Multivariate Menggunakan

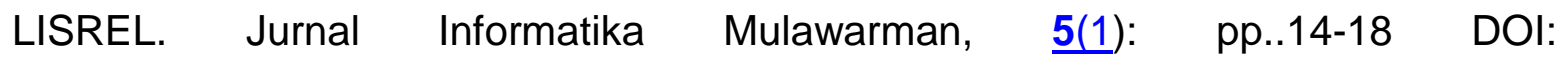
http://dx.doi.org/10.30872/jim.v5i1.48

Ramadiani, R. Atan, M.H. Selamat, C. P. Noraini, A. Rusli (2013). "E-Learning User

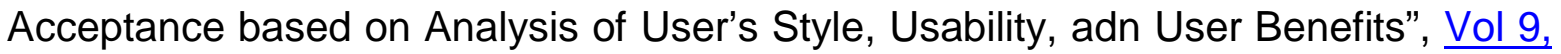
No 1: page 6-12. http://jsi.cs.ui.ac.id/index.php/jsi/issue/view/41

Ramadiani, et al., (2016) User difficulties in e-learning system, 2nd International Conference on Science in Information Technology (ICSITech), Balikpapan, pp. 158162.

Ramadiani, R. Atan, M. H. Selamat, R. Abdullah, N. C. Pa and Azainil, "User difficulties in e-learning system," (2017). 2nd International Conference on Science in Information Technology (ICSITech), Balikpapan, 2016, pp. 158-162. doi:10.1109/ICSITech.2016.7852626 http://ieeexplore.ieee.org/stamp/stamp.jsp?tp=\&arnumber=7852626\&isnumber=785 $\underline{2578}$

Ramadiani, et al., (2017). User Satisfaction Model for e-Learning Using Smartphone. Procedia Computer Science. 116,pp. 373-380. https://doi.org/10.1016/i.procs.2017.10.070

\section{ABOUT THE AUTHORS}

Author Name: Ramadiani currently works as Chairman of the Computer Science Department in Mulawarman University. Lecturer at Faculty of Computer Science and Information Technology in Mulawarman University since December 2001. She does research in Software Engineering, Information Systems (Business Informatics) and Human-computer Interaction. Her current project is 'e-Learning'. She graduated from Computer Doctor of Universiti Putra Malaysia in 2015. 
Author Name: Azainil is a Lecturer in Mulawarman University Samarinda since 1991. He teaches in Master of Management and Education Technology with expertise in Higher Education, e-Learning, Teaching Methods, TQM and Educational Technology.

Author Name: Achmad Nizar Hidayanto is Vice Dean for Resources, Ventura, and General Administration of University of Indonesia. Lecturer at Faculty of Computer Science University of Indonesia since December 2000. He graduated from Computer Doctor of Indonesian University in 2008. His research Interest is Information Systems and Information Technology (Adoption of Technology, E-Government, E -Commerce, Knowledge Management, Human Behavior in Information Systems, Innovation Management). 